\title{
Influence of Seedling Age and Nitrogen Rates on Productivity of Rice (Oryza sativa L.): A Review
}

\author{
Muhammad Mahran Aslam ${ }^{*}$, Muhammad Zeeshan², Ayesha Irum³, \\ Muhammad Umair Hassan ${ }^{2}$, Saif Ali' ${ }^{2}$, Rashid Hussain ${ }^{4}$, Pia Muhammad Adnan Ramzani ${ }^{3}$, \\ Muhammad Farhan Rashid ${ }^{3}$ \\ ${ }^{1}$ Department of Plant Breeding and Genetics, University of Agriculture, Faisalabad, Pakistan \\ ${ }^{2}$ Department of Agronomy, University of Agriculture, Faisalabad, Pakistan \\ ${ }^{3}$ Institute of Soil and Environmental Science, University of Agriculture, Faisalabad, Pakistan \\ ${ }^{4}$ Institute of Horticultural Sciences, University of Agriculture, Faisalabad, Pakistan \\ Email: ${ }^{\text {mahranpbg@gmail.com }}$
}

Received 1 May 2015; accepted 6 June 2015; published 9 June 2015

Copyright (C) 2015 by authors and Scientific Research Publishing Inc.

This work is licensed under the Creative Commons Attribution International License (CC BY). http://creativecommons.org/licenses/by/4.0/

(c) (i) Open Access

\section{Abstract}

Rice is an important crop and the food security of the world is strongly associated with it as it is the staple food of half of the world's population. Among various agro-management practices seedling age and nitrogen rates significantly affected its growth, development and yield components. Rice cultivars performed differently when transplanted in field at varying seedling ages depending upon their genetic makeup and adoptability to certain environmental conditions. Seedling age plays an important role in yield contributing parameters like number of productive tillers, panicle length, filled grains panicle ${ }^{-1}$ and 1000-kernel weight leading to higher paddy yield in different rice cultivars and hybrids. Nitrogen is required in huge quantity in rice production as it is an important constituent of plant parts and processes. Paddy yield increases significantly with the increase in nitrogen rate but after a certain limit yield starts decreasing. Keeping in view the significance of seedling age and nitrogen rates in different rice cultivars and hybrids, an effort has been made to review some research work already conducted and will be helpful to the researchers and scientists to plan future strategies.

\section{Keywords}

Hybrid Rice, Seedling Age, Nitrogen Rates, Paddy Yield

\footnotetext{
${ }^{*}$ Corresponding author.
}

How to cite this paper: Aslam, M.M., Zeeshan, M., Irum, A., Hassan, M.U., Ali, S., Hussain, R., Ramzani, P.M.A. and Rashid, M.F. (2015) Influence of Seedling Age and Nitrogen Rates on Productivity of Rice (Oryza sativa L.): A Review. American Journal of Plant Sciences, 6, 1361-1369. http://dx.doi.org/10.4236/ajps.2015.69135 


\section{Introduction}

Rice is grown in more than a hundred countries with total cultivated area of about 160 million hectares and occupies $11 \%$ of the world's cultivated area with the production of more than 700 million tons [1] [2]. The world population is estimated to increase 9 - 11 billion by the year 2025 out of which 4.3 billion will be dependent on rice for their basic food [3]. So, rice has a leading role in food security. Cultivation of hybrid rice is one of the strategies to increase production per unit area [4] as hybrid rice gives $15 \%-20 \%$ more yield than the commercial high yielding varieties [5]. Among the improved agro-management practices, seedling age plays an important role in enhancing the yield of rice. Age of seedling is a key factor which influences the tiller production, grain formation and other yield contributing parameters [6]. It is the main factor for uniform stand establishment of rice [7] which controls its growth and yield [8]. The use of appropriate aged seedlings for transplantation and its timely planting are important non-cash inputs for attaining the higher yield of rice [9]. Seedling vigor contributes to successive tillering, yield and quality of transplanted rice. Growth and production of rice depend on timely cultivation and growth duration of cultivar which is affected by the age of seedlings at transplantation [10]. All the above and below ground morphological characters of rice plants vary with the seeding rate, age of seedling and growing environment [11] [12].

Nitrogen plays a key role in rice production as it is required in huge amount. It is the essential component of cell molecules including chlorophyll, nucleic acids, amino acids, ATP and a number of plant hormones. It is an important regulator involved in many biochemical processes such as protein synthesis, carbon metabolism and amino acid metabolism [13]. Application of nitrogen fertilizer either in excess or less than the optimum level both affects yield and quality of rice to the significant extent [14]; that's why appropriate fertilizer input is required not only for getting high grain yield but also for attaining maximum profit [15]. The best dose of mineral fertilizer is that which gives maximum economic return at minimum cost [16]. Proper management of crop nutrition is of huge importance as judicious and proper use of fertilizers makes remarkable improvement in the yield and quality of rice [2]. Timing and rate of nitrogen are critical in terms of their impacts on yield contributing parameters as nitrogen increases plant height, leaf size, number of panicles, number of spikelets and filled spikelets per panicle [17]. Nitrogen supply must be available according to the needs of the plant for optimal yield [18].

So, keeping in view the importance of seedling age and nitrogen fertilizer in rice crop, an effort has been made to review some research work done on it which will be helpful for researchers to do further research on it in the future using proper experimental treatments.

\section{Plant Height}

Plant height is an important morphological character of a plant it can vary according to genetic makeup of plant, nutrient status of soil in which it grown, environmental conditions and different types of stresses faced during its life cycle. Various scientists have noticed significant effect of seedling age and nitrogen levels on plant height. Ali et al. [19] evaluated Boro Rice BRRI Dhan 28 with two levels of seedling ages viz. 15 and 30 days old and two levels of water management. They found significant effect of seedling age on plant height. Maximum plant height $(98.3 \mathrm{~cm})$ was recorded when older seedlings of 30 days were transplanted, while minimum plant height $(90.4 \mathrm{~cm})$ was recorded by 15 days old seedlings. Sarkar et al. [20] recorded more plant height $(130.60 \mathrm{~cm})$ at harvest in case of 25 days old seedlings while minimum of $127.54 \mathrm{~cm}$ was observed when seedlings of 35 days were transplanted. It was investigated that seedlings of 14 days age produced taller plants $(89.50 \mathrm{~cm})$ at harvest compared to older seedlings of 21 days [21].

Ehsanullah et al. [22] reported that plant height had increased gradually with the increase in nitrogen fertilization to Basmati rice. Maximum plant height $(107.60 \mathrm{~cm})$ was recorded when nitrogen was applied @ 125 $\mathrm{kg} \cdot \mathrm{ha}^{-1}$, while minimum plant height was $(100.6 \mathrm{~cm})$ obtained when $75 \mathrm{~kg} \mathrm{~N} \cdot \mathrm{ha}^{-1}$ was applied. Awan et al. [23] found the significant effect of nitrogen on plant height of rice variety KSK-133, maximum plant height (80.00 $\mathrm{cm}$ ) was observed when $\mathrm{N}$ was applied @ $156 \mathrm{~kg} \cdot \mathrm{ha}^{-1}$ while minimum of $(69.43 \mathrm{~cm})$ was recorded in case of $110 \mathrm{~kg} \cdot \mathrm{N} \cdot \mathrm{ha}^{-1}$. Kaushal et al. [24] recorded taller plants $(115.6 \mathrm{~cm})$ when nitrogen was applied @ $150 \mathrm{~kg} \cdot \mathrm{ha}^{-1}$ while minimum $(104.1 \mathrm{~cm})$ was obtained in case of $90 \mathrm{~kg} \cdot \mathrm{N} \cdot \mathrm{ha}^{-1}$.

Pramanik and Bera [25] found the significant effect of seedling age and nitrogen fertilization on plant height of hybrid rice. They found maximum plant height $(103.81 \mathrm{~cm}$ and $112.84 \mathrm{~cm})$ when 10 days old seedlings were transplanted and nitrogen was applied @ $200 \mathrm{~kg} \cdot \mathrm{ha}^{-1}$, while minimum plant height $(91.38 \mathrm{~cm}$ and $81.63 \mathrm{~cm})$ was 
observed with the seedlings of 30 days age and with no nitrogen application. El-Rewainy et al. [26] tested rice cultivar Sakha 101 by using four seedling ages (25, 30, 35, 40 days) and four nitrogen levels $(0,48,96,144$ $\left.\mathrm{kg} \cdot \mathrm{ha}^{-1}\right)$. Maximum plant height $(79.80 \mathrm{~cm})$ was obtained by seedlings of 30 days age while 25 days old seedlings gave minimum plant height (70.7). Regarding nitrogen levels maximum plant height $(78.50 \mathrm{~cm})$ was obtained when nitrogen was applied @ $144 \mathrm{~kg} \cdot \mathrm{ha}^{-1}$ and minimum $(71.60 \mathrm{~cm})$ was observed with no nitrogen application.

\section{Total Number of Tillers}

Dynamics of tillering greatly depends on the age of seedlings at transplanting and nitrogen fertilization and this is proved by the findings of many researchers. Ali et al. [19] reported more tillers hill ${ }^{-1}$ (31.5) when younger seedlings of 15 days age were transplanted while minimum (18.0) was observed in case of 30 days old seedlings. Sarkar et al. [20] tested Aman rice using three levels of row arrangement, two types of tiller seedlings and three levels of number of tiller seedling hill ${ }^{-1}$. They found that by transplanting older seedlings of 35 days gave more mean tillers hill ${ }^{-1}$ (13.36), while minimum (12.41) was recorded from 25 days old seedlings. Prabha et al. [21] counted 552 tillers $\mathrm{m}^{-2}$ at harvest by 14 days old seedlings in system of rice intensification. Patra and Haque [9] investigated tillering pattern of rice as influenced by the age of seedlings in the system of rice intensification. They tested seven levels of seedling age viz. 6, 8, 10,12, 1416 and 18 days. Results revealed that maximum tillers plant ${ }^{-1} 31.33$ and 26.73 were obtained by transplanting 10 days old seedlings in the year 2008 and 2009 respectively. Faghani et al. [8] found the significant effect of seedling age on tillering pattern, maximum tillers hill $^{-1}$ (16.3) were recorded by transplanting 25 days old seedlings while 35 days old seedlings gave minimum tillers hill ${ }^{-1}(15.3)$.

Yoseftabar [27] reported maximum tillers (27.6) when nitrogen fertilizer treatment was $150 \mathrm{~kg} \cdot \mathrm{ha}^{-1}$ and minimum (22.8) was obtained by applying nitrogen at the rate $50 \mathrm{~kg} \cdot \mathrm{ha}^{-1}$. Abou-Khalifa [28] evaluated some rice varieties under different nitrogen levels and found maximum tillers $\mathrm{m}^{-2}(704)$ when nitrogen was applied at the rate $220 \mathrm{~kg} \cdot \mathrm{ha}^{-1}$ while minimum (574) was recorded at control having no nitrogen application. Awan et al. [23] evaluated medium grain rice variety KSK-133 under different levels of nitrogen and row spacing. They reported maximum tillering $\mathrm{m}^{-2}$ (601) when nitrogen was applied at maximum rate i.e. $156 \mathrm{~kg} \cdot \mathrm{ha}^{-1}$, while minimum number of tillers (527) were recorded when nitrogen was applied at low rate of $110 \mathrm{~kg} \cdot \mathrm{ha}{ }^{-1}$. Rice CV "Gi-

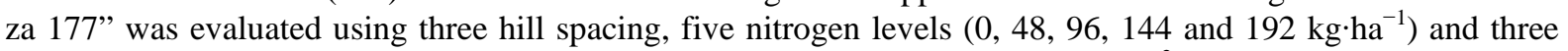
harvest dates during the year 2000 and 2001. It was found that maximum tillers $\mathrm{m}^{-2}$ (439.9 and 477.0) was produced by applying nitrogen @ $192 \mathrm{~kg} \cdot \mathrm{ha}^{-1}$ and minimum number of tillers (373.6 and 360.9) was obtained in control treatment where no nitrogen was applied to soil [29].

Ten days old seedling produced more tillers hill ${ }^{-1}$ (23.32) as compared to 30 days old seedlings which conceived minimum number of tillers (15.33). Meanwhile nitrogen also had significant effect on number of tillers and maximum number of tillers (26.73) given by $200 \mathrm{~kg} \cdot \mathrm{N} \cdot \mathrm{ha}^{-1}$ while control with no nitrogen application produced minimum number of tillers (11.93) during the year 2011 [25].

\section{Productive Tillers}

Tillers are side shoot rise from the base of plant and play major role in the yield of a crop. Productive tillers are most important factor which determines the yield of crop, significant effect of seedling age and nitrogen levels on productive tillers was observed by many researchers. Ali et al. [19] reported more effective tillers hill ${ }^{-1}$ (24.9) when seedlings of 15 days age were transplanted while 30 days old seedlings gave minimum number of effective tillers (15.6). Sarkar et al. [20] did not find significant effect of seedlings age on effective tillers hill ${ }^{-1}$. They recorded 9.24 and 9.08 effective tillers hill ${ }^{-1}$ in case of 25 and 35 days old seedlings which were statistically same. It was observed that younger seedlings of 14 days age produced more productive tillers $\mathrm{m}^{-2}(501)$ as compared to older seedlings which gave minimum (401) productive tillers $\mathrm{m}^{-2}$ [6] [21] observed that 4 week old seedlings produced more effective tillers hill ${ }^{-1}$ (8.26) while minimum number of effective tillers was obtained from 2 week old seedlings.

Yoseftabar [27] reported that productive tillers increased significantly by increasing level of nitrogen. Maximum numbers of productive tillers (21.81) were obtained when nitrogen was applied at maximum rate 150 $\mathrm{kg} \cdot \mathrm{ha}^{-1}$ while minimum numbers of productive tillers (17.15) were given by minimum level of nitrogen 50 $\mathrm{kg} \cdot \mathrm{ha}^{-1}$. Hasanuzzaman et al. [30] observed more productive tillers hill ${ }^{-1}$ (11.42) when $200 \mathrm{~kg}$ nitrogen was used 
per hectare while minimum value (10.12) was given by control having no nitrogen application. Ehsanullah et al. [22] recorded more productive tillers hill ${ }^{-1}$ (18.00) when nitrogen was applied @ $125 \mathrm{~kg} \cdot \mathrm{ha}^{-1}$, while minimum (11.67) was observed when nitrogen was applied at low rate of $75 \mathrm{~kg} \cdot \mathrm{ha}^{-1}$. Kaushal et al. [24] counted more productive tillers $\cdot \mathrm{m}^{-2}(48.3)$ when maximum level of nitrogen $\left(150 \mathrm{~kg} \cdot \mathrm{ha}^{-1}\right)$ was applied.

Hybrid rice was tested using three levels of seedling age and five levels of nitrogen. Results revealed that younger seedlings of 10 days age produced significantly more effective tillers hill ${ }^{-1}$ (17.07 and 18.90) during the year 2010 and 2011, while minimum (10.08 and 11.28) was observed from seedlings of 30 days. Regarding nitrogen levels the number of effective tillers hill ${ }^{-1}$ increased gradually with increase in nitrogen from 0 to 150 $\mathrm{kg} \cdot \mathrm{ha}^{-1}$ and then decreased with further with an increase in nitrogen up to $200 \mathrm{~kg} \cdot \mathrm{ha}^{-1}$. Maximum effective tillers hill ${ }^{-1}$ (20.03 and 22.14) were given by $150 \mathrm{~kg} \cdot \mathrm{N} \cdot \mathrm{ha}^{-1}$ and minimum value (7.14 and 8.23) was recorded at control during the year 2010 and 2011 [25].

\section{Panicle Length}

Panicle length also favors the increase in the numbers of spikelets per panicle. Four rice cultivars were tested using three levels of seedling age (27, 30 and 35 days). Panicle length was significantly affected by seedling age. Seedlings of 27 days age gave maximum $(22.95 \mathrm{~cm})$ panicle length followed by 30 and 35 days old seedlings. Minimum Panicle length (21.04) was recorded from older seedlings of 35 days [31]. Another group of scientists reported that panicle length was not significantly affected by seedling age. Thirty days old seedlings gave mean maximum $(23.67 \mathrm{~cm})$ and minimum $(21.38 \mathrm{~cm})$ panicle length, while 15 days old seedlings recorded a mean panicle length of $23.41 \mathrm{~cm}$ [19]. Sarkar et al. [20] found significant effect of seedling age of panicle length, they recorded more panicle length $(27.98 \mathrm{~cm})$ from seedlings of 25 days age while minimum $(27.36 \mathrm{~cm})$ from older seedlings of 35 days. Prabha et al. [21] reported more panicle length $(24.1 \mathrm{~cm})$ by transplanting younger seedlings of 14 days age compared with older seedlings of 21 days which received minimum panicle length of 18.8 $\mathrm{cm}$ in system of rice intensification.

Patra and Haque [9] investigated seedling ages in order to determine their significance on yield and yield contributing parameters of rice under system of rice intensification. They found higher panicle length $(22.55 \mathrm{~cm})$ by transplanting 10 days old seedlings and minimum $(18.09 \mathrm{~cm})$ was recorded from 6 days old seedlings. Bagheri et al. [32] conducted an experiment to determine the effect of seedling age and potassium rates on lodging and yield components of rice. Panicle length was significantly affected by seedling age and maximum panicle length $(26.16 \mathrm{~cm})$ was shown by transplanting 30 days old seedlings followed by 20 and 40 days age. Minimum panicle length $(23.78 \mathrm{~cm})$ was given by transplanting 40 days old seedlings.

Yoseftabar [27] noticed that panicle length increased with an increase in nitrogen fertilization, maximum panicle length $\left(28.64 \mathrm{~cm}\right.$ ) was obtained by applying $300 \mathrm{~kg} \cdot \mathrm{N} \cdot \mathrm{ha}{ }^{-1}$ while minimum was counted when nitrogen was applied @ $100 \mathrm{~kg} \cdot \mathrm{ha}^{-1}$. Abou-Khalifa [28] checked some rice varieties under different levels of nitrogen and found the significant effect of nitrogen on panicle length. Nitrogen fertilization at higher rate gave rise to increase panicle length $(20.81 \mathrm{~cm})$ while control having no nitrogen application gained minimum panicle length $(18.23 \mathrm{~cm})$. Fine rice was evaluated using nitrogen fertilization and seedling density. It was observed that initially panicle length increased with increase in nitrogen and then decreased with further increase. Application of $100 \mathrm{~kg} \cdot \mathrm{N} \cdot \mathrm{ha}^{-1}$ gave maximum panicle length $(29.17 \mathrm{~cm})$ while minimum $(27.20 \mathrm{~cm})$ was recorded in case of 75 $\mathrm{kg} \cdot \mathrm{N} \cdot \mathrm{ha}^{-1}$ [22]. Maximum panicle length $(22.70 \mathrm{~cm})$ was recorded when $\mathrm{N}$ was applied @ $200 \mathrm{~kg} \cdot \mathrm{ha}{ }^{-1}$ in case of Egyptian hybrid. Further increase up to $400 \mathrm{~kg} \cdot \mathrm{N} \cdot \mathrm{ha}^{-1}$ decreased panicle length by $1.44 \mathrm{~cm}$ from maximum [5].

\section{Number of Spikelets/Grains Panicle ${ }^{-1}$}

The individual unit of spike is termed as spikelet. Greater the number of spikelets greater will be grain yield and vice versa. Rahimpour et al. [31] checked the effect of seedling age on rice cultivars and found the significant effect of seedling age on number of spikelets panicle ${ }^{-1}$. Maximum number of spikelets (114.6) was recorded with the seedlings of 27 days age while minimum (106.4) was recorded in case of 30 days old seedling. Brar et al. [33] reported that seedling age had no significant effect on number of grains per panicle. Seedlings of 3045 and 60 days produced similar number of grains panicle ${ }^{-1}$. It was observed in a study that 25 days old seedlings produced more number spikelets panicle ${ }^{-1}(170.79)$ as compared to seedlings of 35 days age [20] while in another study it was noted that seedling age had no significant effect on number of spikelets panicle ${ }^{-1}$ and researchers recorded similar number of spikelets (100.7 and 103.8) in case of 25 and 35 days old seedlings [8]. 
The effect of seedling age was tested under the system of rice intensification and it was observed that younger seedlings (9 and 12 days) produced significantly higher number of grains panicle ${ }^{-1}$ (159.33 and 158.13) as compared to older seedlings of 18 days which gave minimum (146.87) grains panicle $^{-1}$ [34].

Yoseftabar [27] reported that number of grains panicle ${ }^{-1}$ increased significantly with increase in nitrogen rate and maximum number of grains panicle ${ }^{-1}$ (209.85) were recorded when nitrogen was applied @ $300 \mathrm{~kg} \cdot \mathrm{ha}^{-1}$ while minimum (190.31) was observed at $100 \mathrm{~kg} \cdot \mathrm{N} \cdot \mathrm{ha}^{-1}$. In another field study Yoseftabar [27] found more grains panicle $^{-1}$ (96.51) when nitrogen was applied @ $150 \mathrm{~kg} \cdot \mathrm{ha}^{-1}$ while minimum (94.94) was obtained at 50 $\mathrm{kg} \cdot \mathrm{N} \cdot h \mathrm{~h}^{-1}$. Abou-Khalifa [28] counted higher number of grains panicle ${ }^{-1}$ (117) when nitrogen was applied at maximum rate while minimum (105) was recorded at control with no nitrogen application during the year 2011. Nitrogen applied at higher rate of $156 \mathrm{~kg} \cdot \mathrm{ha}^{-1}$ produced significantly more number of grains panicle ${ }^{-1}(132.97)$ while minimum (119.43) was recorded in case of $110 \mathrm{~kg} \cdot \mathrm{N} \cdot \mathrm{ha}^{-1}$ [23].

A rice hybrid $\mathrm{H}_{1}$ was tested using three levels of seedling age and four levels of nitrogen rate. Seedling age and nitrogen rates both significantly affected the number of grains panicle ${ }^{-1}$. Maximum value of grains panicle ${ }^{-1}$ (110) was observed where younger seedlings (20 days old) were transplanted while minimum (98) was given by older seedlings of 40 days age. Regarding nitrogen levels maximum number of grains panicle ${ }^{-1}$ (129) was recorded using higher rate $\left(164 \mathrm{~kg} \cdot \mathrm{ha}^{-1}\right)$ of nitrogen while minimum (83) was given by control having no nitrogen application [35].

\section{Filled Grains Panicle ${ }^{-1}$}

Several scientists have made efforts in order to assess the number of filled grains panicle ${ }^{-1}$ as affected by seedling age and nitrogen levels. Rahimpour et al. [31] found more filled grains panicle ${ }^{-1}$ (110.6) when younger seedlings of 27 days were transplanted while minimum number of grains panicle ${ }^{-1}(100.6)$ was given by seedlings of 30 days age. Ali et al. [19] reported the significant effect of seedling age on number of filled grains panicle $^{-1}$, maximum number of filled grains (188) was obtained by transplanting younger seedlings (15 days) while minimum number of filled grains (170) was recorded using older seedlings of 30 days age. More number of grains panicle ${ }^{-1}$ (140.99) was reported by transplanting younger seedlings (25 days) while minimum (135.44) was observed using older seedlings of 35 days age [20]. Prabha et al. [21] recorded maximum number of filled spikelets panicle $^{-1}$ (211) in the treatment where 14 days old seedlings were transplanted while minimum number (141) was given by 21 days old seedlings. Similarly, Patra and Haque [9] found more number of filled grains panicle $^{-1}$ (123.30) when 10 days old seedlings were transplanted while minimum (86.20) was given by 6 days old seedlings under the system of rice intensification.

Hasanuzzaman et al. [30] reported the significant effect of nitrogen rates on number of filled grains panicle ${ }^{-1}$. They reported maximum value (154.67) of filled grains when nitrogen was applied as urea super granules @ 75 $\mathrm{kg} \cdot \mathrm{ha}^{-1}$ which was statistically at par with 80,120 and $160 \mathrm{~kg} \cdot \mathrm{N} \cdot \mathrm{ha}^{-1}$ and minimum value (126.16) was given by control with no nitrogen application. Whereas Ehsanullah et al. [22] reported that different nitrogen levels had no significant effect on number of kernels panicle ${ }^{-1}$. Metwally et al. [5] checked the response of hybrid rice to different levels of nitrogen and found that number of filled grains panicle ${ }^{-1}$ increased significantly with increase in nitrogen level up to certain limit and then starts declining with further increase. According to the findings of Kandil et al. [29] maximum number of filled grains panicle ${ }^{-1}$ were obtained at maximum level of nitrogen i.e. $192 \mathrm{~kg} \cdot \mathrm{ha}^{-1}$ while minimum value (81.6) was given by control having no nitrogen application.

\section{1000-Kernel Weight}

The 1000 kernal weight is key factor in determining the final grain yield, and 1000 kernal weight may vary among cultivars or may vary according to conditions. The 1000-kernel weight is the important indicator of paddy yield. Rahimpour [31] investigated those 27 days old seedlings produced maximum 1000-kernel weight (22.08 g) as compared to 30 days old seedlings which gave minimum value of $20.33 \mathrm{~g}$. Age of seedlings significantly influenced 1000-grain weight and the maximum 1000 grain weight (22.61 g) were obtained by transplanting younger seedlings of 15 days while and the minimum grains (21.00 g) were obtained from 30 days old seedlings [19]. Whereas Brar et al. [33] reported that seedling age had no significant effect on 1000-kernel weight and seedlings of 30, 45 and 60 days conceived statistically similar thousand kernel weight. According to the findings of [20] maximum 1000-kernel weight (26.40 g) was obtained by transplanting younger seedlings (25 days) while minimum (25.98 g) was given by older seedlings (35 days). 
The 1000-grain weight increased significantly with increase in nitrogen rates. Yoseftabar [27] reported maximum 1000-kernel weight (25.6 g) at maximum nitrogen level $\left(150 \mathrm{~kg} \cdot \mathrm{ha}^{-1}\right)$ and minimum value $(23.3 \mathrm{~g})$ was recorded when nitrogen was applied at low rate of $50 \mathrm{~kg} \cdot \mathrm{ha}^{-1}$. Abou-Khalifa [28] tested rice varieties under different levels of nitrogen and found significant effect of nitrogen on 1000-kernel weight. It was observed that 1000-grain weight increased with increase in nitrogen level. Maximum weight (24.95 g) was obtained when nitrogen was applied @ $220 \mathrm{~kg} \cdot \mathrm{ha}^{-1}$ while minimum (21.63 g) was given by control $\mathrm{N}_{0}$. Hasanuzzaman et al. [30] reported the significant effect of nitrogen rates on 1000-kernel weight. They reported maximum value (29.35 g) of 1000-kernel weight when nitrogen was applied as urea super granules @ $75 \mathrm{~kg} \mathrm{ha}^{-1}$ and minimum value (27.86 g) was given by control with no nitrogen application.

Pramanik and Bera [25] evaluated hybrid rice to three levels of seedling age and five levels of nitrogen. They observed that 1000-kernel weight affected significantly by different levels of seedling age and nitrogen rates. Young seedlings of 10 days age produced maximum thousand grain weight (23.80 g) while minimum (22.86 g) was recorded from older seedlings of 30 days age. Thousand Kernel weight increased gradually with increase in nitrogen rate from 0 to $150 \mathrm{~kg} \cdot \mathrm{ha}^{-1}$ maximum 1000-kernel weight $(24.11 \mathrm{~g})$ was obtained with the application of $150 \mathrm{~kg} \cdot \mathrm{N} \cdot \mathrm{ha}^{-1}$ and it decreased (to $23.87 \mathrm{~g}$ ) with further increase in nitrogen up to $200 \mathrm{~kg} \cdot \mathrm{ha}^{-1}$.

\section{Paddy Yield}

Paddy yield is the function of number of productive tillers, filled grains panicle ${ }^{-1}$ and 1000-kernel weight. Seedling age and nitrogen levels significantly influenced paddy yield which is proved by a number of scientists based on their field experiments. Rahimpour et al. [31] investigated the effect of seedling age on rice cultivars. Younger seedlings of 27 days age produced higher grain yield $\left(5.82 \mathrm{t}^{\mathrm{h}} \mathrm{ha}^{-1}\right)$ as compared to older seedlings of 35 days which gave minimum paddy yield $\left(5.38 \mathrm{t}^{\mathrm{h}} \cdot \mathrm{a}^{-1}\right)$. Ali et al. [19] tested Boro Rice BRRI Dhan-28 to different seedling ages. They found maximum grain yield $\left(8.77 \mathrm{t}^{\cdot} \cdot \mathrm{ha}^{-1}\right)$ when young seedlings of 15 days were transplanted while minimum $\left(6.90 \mathrm{t}^{\mathrm{h}} \mathrm{ha}^{-1}\right)$ was observed in case of aged seedlings of 30 days. Brar et al. [33] also reported significant effect of seedling age on paddy yield. According to their findings younger seedlings of 30 days age produced more grain yield $\left(6.82 \mathrm{t}^{\mathrm{h} h \mathrm{~h}^{-1}}\right)$ as compared to older seedlings of 60 days which produced minimum grain yield $\left(6.47 \mathrm{t}^{\mathrm{h}} \mathrm{ha}^{-1}\right)$. Sarkar et al. [20] also recorded more grain yield $\left(4.13 \mathrm{t} \cdot \mathrm{ha}^{-1}\right)$ from younger seedlings of 25 days age while minimum $\left(3.68 \mathrm{t}^{\mathrm{h}} \mathrm{ha}^{-1}\right)$ was obtained from older seedlings of 35 days. In system of rice intensification rice variety "Ranjit" was tested using seven levels of seedling age (6, 8, 10, 12, 14, 16 and 18 days). It was reported that seedling age significantly affected grain yield and maximum grain yield (7.11 $\mathrm{t} \cdot \mathrm{ha}^{-1}$ ) was obtained by using 10 days old seedlings while minimum was given by 6 days old seedlings.

Yoseftabar [27] tested hybrid rice using three levels of nitrogen and reported maximum paddy yield (8611.0 $\left.\mathrm{kg} \cdot \mathrm{ha}^{-1}\right)$ by applying maximum level of nitrogen $\left(300 \mathrm{~kg} \cdot \mathrm{ha}^{-1}\right)$ while minimum grain yield $\left(6989.8 \mathrm{~kg} \cdot \mathrm{ha}^{-1}\right)$ was obtained at low level of nitrogen $\left(100 \mathrm{~kg} \cdot \mathrm{ha}^{-1}\right)$. Whereas, Sharma et al. [36] recorded maximum grain yield (5015 kg $\cdot \mathrm{ha}^{-1}$ ) when nitrogen was applied @ $90 \mathrm{~kg} \cdot \mathrm{ha}^{-1}$ to basmati cultivars while yield decreased with further increase in nitrogen to $120 \mathrm{~kg} \cdot \mathrm{ha}^{-1}$. Abou-Khalifa [28] evaluated rice varieties to different levels of nitrogen and found higher grain yield $\left(10.64 \mathrm{t}^{\mathrm{h}} \mathrm{h}^{-1}\right)$ when nitrogen was applied at maximum level $\left(220 \mathrm{~kg} \cdot \mathrm{ha}^{-1}\right)$ whereas minimum (7.11 tha $\left.\mathrm{a}^{-1}\right)$ was recorded in case of no nitrogen application. Awan et al. [23] also reported maximum grain yield $\left(5461.03 \mathrm{~kg} \cdot \mathrm{ha}^{-1}\right)$ of rice variety, KSK-133 when nitrogen was applied at higher rate $\left(156 \mathrm{~kg} \cdot \mathrm{ha}^{-1}\right)$ while minimum (4354.60 kg ha $\left.{ }^{-1}\right)$ was recorded from low level of nitrogen fertilizer $\left(110 \mathrm{~kg} \cdot \mathrm{ha}^{-1}\right)$. Pramanik and Bera [25] recorded more grain yield $\left(5946 \mathrm{~kg} \cdot \mathrm{ha}^{-1}\right)$ when younger seedlings of 10 days were transplanted in case of hybrid rice. Regarding nitrogen levels grain yield increased gradually with increase in nitrogen up to 150 $\mathrm{kg} \mathrm{ha}^{-1}$ and maximum grain yield $\left(6652 \mathrm{~kg} \cdot \mathrm{ha}^{-1}\right)$ was obtained at this level, with further increase in nitrogen from this level grain yield decreased. Minimum paddy yield $\left(3916 \mathrm{~kg} \cdot \mathrm{ha}^{-1}\right)$ was observed at no nitrogen application.

\section{Straw Yield}

Ali et al. [19] reported that seedling age had no significant effect on straw yield. Whereas Sarkar et al. [20] found significant effect of seedling age on straw yield. They recorded maximum straw yield $\left(5.61 \mathrm{t} \cdot \mathrm{ha}^{-1}\right)$ with older seedlings (35 days) while younger seedlings (25 days) produced minimum straw yield ( $\left.4.81 \mathrm{t}^{\mathrm{h}} \mathrm{ha}^{-1}\right)$. Bagheri et al. [32] recorded more straw yield $\left(846.90 \mathrm{~g} \cdot \mathrm{m}^{-2}\right)$ when 30 days old seedlings were transplanted while minimum $\left(635.80 \mathrm{~g} \cdot \mathrm{m}^{-2}\right)$ was observed in case of 20 days old seedling. In another field study it was found that 
younger seedlings of 9 days age produced maximum straw yield $\left(7019 \mathrm{~kg} \cdot \mathrm{ha}^{-1}\right)$ while minimum $\left(6716 \mathrm{~kg} \cdot \mathrm{ha}^{-1}\right)$ was given by 21 days old seedlings [34]. Faruk et al. [6] [37] reported that straw yield was significantly affected by age of seedlings. Maximum straw yield $\left(5.54 \mathrm{t}^{\mathrm{t}} \mathrm{ha}^{-1}\right)$ was recorded by transplanting 4 weeks old seedlings while minimum straw yield $\left(4.24 \mathrm{t}^{\mathrm{h}} \mathrm{h}^{-1}\right)$ was obtained where 2 week old seedlings were transplanted.

Sharma et al. [36] recorded maximum straw yield $\left(7288 \mathrm{~kg} \cdot \mathrm{ha}^{-1}\right)$ with the application of $90 \mathrm{~kg} \mathrm{~N} \cdot \mathrm{ha}{ }^{-1}$ which was statistically at par with the application of $120 \mathrm{~kg} \cdot \mathrm{N} \cdot \mathrm{ha}^{-1}$. Hasanuzzaman et al. [30] reported maximum straw yield $\left(15 \mathrm{t} \cdot \mathrm{ha}^{-1}\right)$ when nitrogen was applied @ $975 \mathrm{~kg} \cdot \mathrm{ha}^{-1}$ as urea super granules while minimum $\left(5.5 \mathrm{t} \cdot \mathrm{ha} \mathrm{a}^{-1}\right)$ was obtained under control. Awan et al. [23] observed that straw yield increased significantly with increase in nitrogen level. Results revealed that maximum straw yield $\left(9662.03 \mathrm{~kg} \cdot \mathrm{ha}^{-1}\right)$ was obtained by applying nitrogen @ $156 \mathrm{~kg} \mathrm{ha}^{-1}$ while minimum $\left(7867.27 \mathrm{~kg} \cdot \mathrm{ha}^{-1}\right.$ ) was recorded with the application of $110 \mathrm{~kg} \cdot \mathrm{N} \cdot \mathrm{ha}^{-1}$. Pramanik and Bera [25] also reported maximum straw yield $\left(7734 \mathrm{~kg} \cdot \mathrm{ha}^{-1}\right)$ with the application of higher rate $\left(200 \mathrm{~kg} \mathrm{ha}^{-1}\right)$ of nitrogen fertilizer while minimum value $\left(5213 \mathrm{~kg} \cdot \mathrm{ha}^{-1}\right)$ of straw yield was obtained at control with no nitrogen application.

\section{Harvest Index}

Harvest index is the ration between grain yield and biological yield. Harvest index was significantly influenced by seedling age and maximum harvest index (0.47\%) was recorded by transplanting younger seedlings of 15 days age while minimum (0.42\%) was obtained from transplanting 30 days old seedlings [19]. Similar findings were reported by Sarkar et al. [20] with maximum harvest index of $0.46 \%$ when younger seedlings of 25 days age were transplanted while minimum $(0.40 \%)$ was given by 35 days old seedlings. Ginigaddara and Ranamukhaarachchi [7] reported maximum harvest index $(0.51 \%)$ by transplanting 9 days old seedlings.

Ehsanullah et al. [22] reported highest harvest index (38.32\%) when nitrogen was applied @ $100 \mathrm{~kg} \cdot \mathrm{ha}^{-1}$ to basmati rice. Awan et al. [23] found that harvest index was not significantly affected by nitrogen rates. Whereas Pramanik and Bera [25] reported significant effect of nitrogen on harvest index, maximum harvest index (47.07\%) was observed when nitrogen was applied @ $150 \mathrm{~kg} \cdot \mathrm{ha}^{-1}$ while minimum (42.60\%) was obtained in case of control having no nitrogen application.

\section{Discussion}

The increase in plant height from younger seedlings might be due to better stand establishment and less transplanting shock because of lesser leaf area which enhanced cell division causing more stem elongation [38]. The young seedlings produced more plant height and number of tillers hill ${ }^{-1}$ due to better roots growth, cell division and cell enlargement having increased photosynthetic rate [38]. The younger seedling also produced more number of productive tillers due to less root damage, reduced transplanting shock, better stand establishment and more efficient use of nutrients, light, space etc. which increased plants hill ${ }^{-1}$ and consequently leading to increased productive tillers $\mathrm{m}^{-2}$ [26]. Nitrogen also increases the number of tillers in because it favors many metabolic processes within the plant system.

Greater panicle length from younger seedlings is because of their good growth and development ability as compared to older ones, optimum supply of essential nutrients can also accelerate the panicle formation and panicle growth. Younger seedlings produced maximum numbers of spikelet per panicle when compared with older seedling due to their better nutrition uptake and growth rate, optimum supply of essential nutrients can also uplift the panicle formation and panicle growth which gives maximum number of grains per panicle [35]. Grain yield in rice depends mainly on number of spikelet per panicle, spikelet filling \% and 1000-grain weight younger seedlings increased the 1000 grain weight due to the proper crop growth, development, assimilates synthesis and translocation to the grains. Higher rates of applied nitrogen also increased grain weight due to the increase in chlorophyll content of leaves which led to higher photosynthetic rate and ultimately availability plenty of photosynthates during grain development [28].

Higher paddy yield by younger seedlings is might be due to the vigorous and healthy growth, more productive tillers and leaves ensuring larger resource utilization as compared to the old age seedlings [25]. Increased grain yield by high rates of applied nitrogen may be due to the favorable growth with higher nutrient uptake, more translocation of carbohydrates towards the sink which increased yield attributes and resulted in producing higher grain yield [39]. Higher $\mathrm{HI}$ in younger seedlings might be due to the better crop growth, development and assimilates translocation to the grains, similar findings were reported by [25]. 


\section{Conclusion}

Based on the review of past work it is concluded that yield contributing parameters are significantly affected by seedling age and nitrogen rates in rice and there is a dire need of developing site specific production technology for different rice cultivars and hybrids. Seedling age and nitrogen rate are important components of production technology in case of rice and varied by site properties and set of its environmental conditions. So, optimum aged seedlings and nitrogen rates should be used according to genetic makeup of crop in order to enhance paddy yield in different environments. Rice paddy production in the country is decreasing because of seedling age and nutrition deficiency. It is the need of the time to enhance the seedling vigor and to optimize the age of transplanting. It is directed to use a wide range of seedling age and nitrogen level for better and result-oriented research in the above field.

\section{References}

[1] IRRI (International Rice Research Institute) (2010) Scuba Rice: Breeding Flood-Tolerance to Asia’s local Mega Rice Varieties. International Rice Research Institute, Los Baños, Philippines.

[2] Alam, M.M., Hassanuzzaman, M. and Nahar, K. (2009) Tiller Dynamics of Three Irrigated Rice Varieties under Varying Phosphorus Levels. American-Eurasian Journal of Agronomy, 2, 89-94.

[3] Bisne, R., Sarawgi, A.K. and Verulkar, S.B. (2009) Study of Heritability, Genetic Advance and Variability for Yield Contributing Characters in Rice. Bangladesh Journal of Agricultural Research, 34, 175-179.

[4] Obulamma, U., Reddy, M.R. and Kumari, C.R. (2004) Effect of Spacing and Number of Seedlings per Hill on Yield Attributes and Yield of Hybrid Rice. Madras Agricultural Journal, 91, 344-347.

[5] Metwally, T.F., Gewaily, E.E. and Naeem, S.S. (2011) Nitrogen Response Curve and Nitrogen Use Efficiency of Egyptian Hybrid Rice. Journal of Agricultural Research, 37, 73-84.

[6] Faruk, M.O., Rahman, M.A. and Hasan, M.A. (2009) Effect of Seedling Age and Number of Seedling per Hill on the Yield and Yield Contributing Characters of Brri Dhan 33. International Journal of Sustainable Crop Production, 4, 58-61.

[7] Ginigaddara, G.A.S. and Ranamukhaarachchi, S.L. (2011) Study of Age of Seedlings at Transplanting on Growth Dynamics and Yield of Rice under Alternating Flooding and Suspension of Irrigation of Water Management. Recent Research in Science and Technology, 3, 76-88.

[8] Faghani, R., Mobasser, H.R., Dehpor, A.A. and Kochaksarai, S.T. (2011) The Effect of Planting Date and Seedling Age on Yield and Yield Components of Rice (Oryza sativa L.) Varieties in North of Iran. African Journal of Agricultural Research, 6, 2571-2575.

[9] Patra, P.S. and Haque, S. (2011) Effect of Seedling Age on Tillering Pattern and Yield of Rice (Oryza sativa L.) under System of Rice Intensification. ARPN Journal of Agricultural and Biological Science, 6, 33-35.

[10] Mishra, A. and Salokhe, V.M. (2008) Seedling Characteristics and the Early Growth of Transplanted Rice under Different Water Regimes. Experimental Agriculture, 44, 365-383. http://dx.doi.org/10.1017/S0014479708006388

[11] Himeda, M. (1994) Cultivation Technique of Rice Nursling Seedlings: Review of Research Papers and Its Future Implementation. Agriculture and Horticulture, 69, 679-683.

[12] Sasaki, R. (2004) Characteristics and Seedlings Establishment of Rice Nursling Seedlings. Japan Agricultural Research Quarterly, 38, 7-13.

[13] Cai, H.M., Lu, Y.G., Xia, W.B., Zhu, T. and Lian, X.M. (2012) Transcriptome Response to Nitrogen Starvation in Rice. Journal of Biosciences, 37, 731-747.

[14] Manzoor, Z., Awan, T.H., Safdar, M.E., Ali, R.I., Ashraf, M.M. and Ahmad, M. (2006) Effect of Nitrogen Levels on Yield and Yield Components of Basmati Rice. Journal of Agricultural Research, 44, 115-120.

[15] Khuang, T.Q., Huan, T.T. and Hach, C.V. (2008) Study on Fertilizer Rates for Getting Maximum Grain Yield and Profitability of Rice Production. Omonrice, 16, 93-99.

[16] Ananthi, T., Amanullah, M.M. and Subramanian, K.S. (2010) Influence of Mycorrhizal and Synthetic Fertilizers on Soil Nutrient Status and Uptake in Hybrid Maize. Madras Agricultural Journal, 97, 374-378.

[17] Shakouri, M.J., Vajargah, A.V., Gavabar, M.G., Mafakheri, S. and Zargar, M. (2012) Rice Vegetative Response to Different Biological and Chemical Fertilizer. Advances in Environmental Biology, 6, 859-863.

[18] Azarpour, E., Tarighi, F., Moradi, M. and Bozorgi, H.R. (2011) Evaluation Effect of Different Nitrogen Fertilizer Rates under Irrigation Management in Rice Farming. World Applied Sciences Journal, 13, 1248-1252.

[19] Ali, M.S., Hasan, M.A., Sikder, S., Islam, M.R. and Hafiz, M.H.R. (2013) Effect of Seedling Age and Water Manage- 
ment on the Performance of Boro Rice (Oryza sativa L.) Variety BRRI Dhan 28. Agriculturists, 11, 28-37. http://dx.doi.org/10.3329/agric.v11i2.17484

[20] Sarkar, M.A.R., Paul, S.K. and Hossain, M.A. (2011) Effect of Row Arrangement, Age of Tiller Seedling and Number of Tiller Seedlings per Hill on Performance of Transplant Aman Rice. Journal of Agricultural Science, 6, 61-63. http://dx.doi.org/10.4038/jas.v6i2.3860

[21] Prabha, A.C., Thiyagrajan, T.M. and Senthivelu, M. (2011) System of Rice Intensification Principles on Growth Parameters, Yield Attributes and Yield of Rice (Oryza sativa L.). Journal of Agronomy, 10, 27-33. http://dx.doi.org/10.3923/ja.2011.27.33

[22] Ehsanullah, Jabran, K., Asghar, G., Hussain, M. and Rafiq, M. (2012) Effect of Nitrogen Fertilization and Seedling Density on Fine Rice Yield in Faisalabad, Pakistan. Soil \& Environment, 31, 152-156.

[23] Awan, T.H., Ali, R., Manzoor, Z., Ahmed, M. and Akhtar, M. (2011) Effect of Different Nitrogen Levels and Row Spacing on the Performance of Newly Evolved Medium Grain Rice Variety, KSK-133. Journal of Animal and Plant Sciences, 21, 231-234.

[24] Kaushal, A.K., Rana, N.S., Singh, A., Neeray, S. and Strivastav, A. (2010) Response of Levels and Split Application of Nitrogen in Green Manured Wetland Rice (Oryza sativa L.). Asian Journal of Agricultural Sciences, 2, 42-46.

[25] Pramanik, K. and Bera, A.K. (2013) Effect of Seedling Age and Nitrogen Fertilizer on Growth, Chlorophyll Content, Yield and Economics of Hybrid Rice (Oryza sativa L.). International Journal of Agronomy and Plant Production, 4, 3489-3499.

[26] El-Rewainy, I.M., Hamoud, S.A., Metwaly, T.F. and Sedeek, S.E. (2007) Response of Two Rice Cultivars to Different Seedling Ages and Nitrogen Levels. African Crop Science Conference Proceedings, 8, 1937-1941.

[27] Yoseftabar, S. (2013) Effect Nitrogen Management on Panicle Structure and Yield in Rice (Oryza sativa L.). International Journal of Agriculture and Crop Sciences, 5, 1224-1227.

[28] Abou-Khalifa, A.A.B. (2012) Evaluation of Some Rice Varieties under Different Nitrogen Levels. Advances in Applied Science Research, 3, 1144-1149.

[29] Kandil, A.A., El-Kalla, S.E., Badawi, A.T. and El-Shayb, O.M. (2010) Effect of Hill Spacing, Nitrogen Levels and Harvest Date on Rice Productivity and Grain Quality. Crop \& Environment, 1, 22-26.

[30] Hasanuzzaman, M., Ali, M.H., Karim, M.F., Masum, S.M. and Mahmud, J.A. (2012) Response of Hybrid Rice to Different Levels of Nitrogen and Phosphorus. International Research Journal of Applied and Basic Sciences, 3, 25222528.

[31] Rahimpour, L., Daliri, M.S. and Mousavi, A.A. (2013) Effect of Seedling Age on Yield and Yield Component of Rice Cultivars (Oryza sativa L.). Annals of Biological Research, 4, 72-76.

[32] Bagheri, R., Mobasser, H.R., Malidarreh, A.G. and Dastan, S. (2011) Effect of Seedling Age and Potassium Rates on Morphological Traits Related-Lodging, Yield and Yield Components of Rice (Oryza sativa L.) in Iran. American-Eurasian Journal of Agricultural \& Environmental Sciences, 11, 261-268.

[33] Brar, S.K., Mahal, S.S., Brar, A.S., Vashist, K.K., Sharma, N. and Buttar, G.S. (2012) Transplanting Time and Seedling Age Affect Water Productivity, Rice Yield and Quality in North-West India. Agricultural Water Management, 115, 217-222. http://dx.doi.org/10.1016/j.agwat.2012.09.001

[34] Manjunatha, B.N., Basavarajappa, R. and Pujari, B.T. (2010) Effect of Age of Seedlings on Growth, Yield and Water Requirement by Different System of Rice Intensification. Karnataka Journal of Agricultural Sciences, 23, 231-234.

[35] Salem, A.K.M., ElKhoby, W.M., Abou-Khalifa, A.B. and Ceesay, M. (2011) Effect of Nitrogen Fertilizer and Seedling Age on Inbred and Hybrid Rice Varieties. American-Eurasian Journal of Agricultural \& Environmental Sciences, 11, 640-646.

[36] Sharma, D., Sagwal, P.K., Singh, I. and Sangwan, A. (2012) Influence of Different Nitrogen and Phosphorus Levels on Profitability, Plant Nutrient Content, Yield and Quality in Basmati Cultivars. International Journal of IT, Engineering and Applied Sciences Research, 1, 1-4.

[37] Amin, A.K.M.K. and Haque, M.A. (2009) Seedling Age Influence Rice (Oryza sativa L.) Performance. Philippine Journal Crop Science, 138, 219-226.

[38] Shrirame, M.D., Rajgire, H.J. and Rajgire, A.H. (2000) Effect of Spacing and Seedling Number per Hill on Growth Attributes and Yield of Rice Hybrids under Lowland Condition. Indian Journal of Agronomy, 10, 109-113.

[39] Jayakumar, M. and Krishnasamy, S. (2005) Effect of Irrigation Regimes, Mid Season Drainage and Time of Application of Nitrogen on Hybrid Rice. Madras Agricultural Journal, 92, 415-421. 